\title{
NASIONALISASI PERUSAHAAN-PERUSAHAAN MILIK BELANDA ATAS TANAH KONSESI KESULTANAN DELI (Studi Awal Hilangnya Hak-hak atas Sumber Daya Alam Masyarakat Adat)
}

\author{
Oleh: \\ OK. Saidin \\ Fakultas Hukum Universitas Sumatera Utara \\ E-mail : ok_saidin@yahoo.com
}

\begin{abstract}
The nationalization of Netherland plantation which became the national possession in 1958 , regulated in the Act No. 86 of 1958 was the starting point of the loss of natural resource rights of the Malay indigenous people of Deli and also was the starting point of the conflict between the Malay indigenous people and the plantation party. When the plantation party which belong to the country (now PT Perkebunan Nusantara 2 (Persero)/National Plantation Company 2) was no longer continuing the right as received by the indigenous people from the time of Netherland plantation, third parties' claims without any basis of rights (recht title) were occurred on the land. Nationalization has shown its mistake to nationalize the rights on the land of the society (not the possession of the foreign), whereas the meaning of nationalization is to nationalize what was not belong to the country. Was not the land belong to the Malay Indigenous people of Deli which is the society of Indonesia? Was not the Indigenous people stand as the possessor of this country? But the Act of Nationalization which clearly stated that what is nationalized was the Netherland's companies which were listed in the Company Asset Listing such as Deli Maatschapij, Arrensburg Maatschapij and Deli Rubber Maatschapij. These objects of land were not listed as company asset that belong to foreign company (Netherland's Company). What should have happened was the national company as the receiver post-nationalization was just continuing the vested rights, so that when the vested rights ended, the object of the vested rights (the land) must be given back to the original possessor (Deli Sultanate and Malay Indigenous people of Deli).
\end{abstract}

Key words: Nationalization, Malay Indigenous People

\begin{abstract}
Abstrak
Nasionalisasi perkebunan Belanda menjadi perkebunan milik negara pada tahun 1958, melalui Undang-undang No. 86 Tahun 1958 merupakan awal hilangnya hak-hak sumber daya alam Masyarakat Adat Deli sekaligus merupakan awal konflik masyarakat hukum adat Melayu dengan pihak perkebunan. Ketika pihak perkebunan negara tersebut (sekarang PT. Perkebunan Nusantara 2 (Persero)) tidak lagi meneruskan hak sebagaimana hak yang diterima masyarakat hukum adat dari pihak perkebunan Belanda dahulu, maka bermuculanlah klaim-klaim pihak ketiga yang tidak memiliki alas hak (recht title) di atas lahan tersebut. Nasionalisasi telah memperlihatkan kekeliruannya karena menasionalkan hak-hak atas tanah milik masyarakat (bukan milik asing), padahal pemaknaan nasionalisasi adalah menasionalkan yang bukan milik nasional. Bukankah tanah-tanah itu adalah milik Masyarakat Adat Deli yang notabene adalah rakyat Indonesia ? Bukankah masyarakat hukum adat itu adalah pemilik negeri ini ? Akan tetapi, undang-undang nasionalisasi yang secara tegas menyatakan bahwa yang dinasionalisasi
\end{abstract}


adalah perusahaan Belanda dalam arti yang dinasionalisasi itu adalah asset yang terdaftar dalam Daftar Asset perusahaan semisal Deli Maatschapij, Arrensburg Maatschapij dan Deli Rubber Maatschapij. Obyek tanah tidak terdaftar sebagai asset perusahaan milik perusahaan asing (perusahaan Belanda). Seyogyanya perusahaan negara sebagai penerima asset pasca nasionalisasi hanyalah meneruskan hak-hak konsesi itu (vested rights), sehingga ketika hak konsesi itu berakhir, maka obyek konsesi itu (tanah) harus dikembalikan kepada pemiliknya (Kesultanan dan Masyarakat Adat Deli).

\section{Key Words : Nasionalisasi, Masyarakat Adat Melayu}

\section{A. Pendahuluan}

Kedatangan Nienhuys, seorang pengusaha onderneming (perkebunan) Belanda pada bulan Juli 1863 di tanah Deli - yang kemudian menjadi cikal bakal berdirinya perkebunan-perkebunan asing di Sumatera Timur yang meliputi wilayah masyarakat adat : Bilah, Panai, Kuwaluh, Kota Pinang, Asahan, Batubara, Negeri Padang dan Bedagai, Serdang, Deli dan Langkat - merupakan awal dari sejarah yang panjang yang penuh duka nestapa, tangis derai air mata dan darah serta penuh carut marut. Betapa tidak, kehadiran Nienhuys tersebut telah menjadikan tanah Deli pusat perhatian dunia dengan bisnis perkebunan tembakaunya. Mencontoh dari keberhasilan Nienhuys berdirilah kebun-kebun swasta asing dengan komoditi tidak hanya tembakau akan tetapi berupa karet, coklat, kopi dan kelapa sawit serta teh di Sumatera Timur (sekarang wilayah Provinsi Sumatera Utara). Tanah-tanah lahan perkebunan itu disewa oleh pihak perkebunan (konsesi) dari Sultan/Kepala Masyarakat Adat di Sumatera Timur ketika itu yang tertuang dalam berbagai-bagai Akta Konsesi. Sultan/Kepala Masyarakat Hukum Adat menyewakan tanah itu selama tenggang waktu 75 atau 99 tahun dan ia bertindak untuk dan atas nama masyarakat hukum adat (Di Deli, Serdang dan Langkat masyarakat adat diberi hak untuk bercocok tanam palawija pada masa bera (masa dimana tanah tidak ditanami tembakau, dengan rotasi selama tujuh tahun) untuk satu musim tanam. Tanah itu disebut sebagai tanah jaluran, masyarakatnya disebut "opgezetenen" (rakyat penunggu) yang dikemudian hari ketika haknya diabaikan mereka berjuang yang disebut sebagai BPRPI. Organisasi ini berdiri tahun 1953 yang ketua pertamanya adalah Al-Ustadz Abdul Kadir, kemudian digantikan oleh Afnawi Nuh. Di tangan Afnawi Nuh, BPRPI tumbuh dan menjadi symbol perlawanan masyarakat Melayu terhadap pengabaian hak-hak mereka) yang diketahui oleh Gubernur Jenderal (wakil Pemerintah Hindia Belanda) ketika itu. Contoh-contoh akte konsesi itu dapat dilihat, misalnya Konsesi Dolok Masihul, Konsesi Bajalingge, Konsesi Sei Sikambing D. (Gerard Jansen, 1925). 
Sultan/Kepala Masyarakat Hukum Adat Melayu di Sumatera Timur atas konsesi itu menerima uang penyewaan atas konsesi itu (berupa uang sewa) yang dipergunakan untuk membangun masyarakatnya. Namun demikian, meskipun tanah-tanah itu telah dikonsesikan, hak-hak masyarakat hukum adat tetap dipertahankan. Khusus untuk wilayah Kesultanan Deli hak-hak masyarakat hukum adat di wilayah itu meliputi :

1. Hak untuk bercocok tanam di lahan konsesi selama tanah tidak ditanami tembakau.

2. Hak untuk mendapatkan lahan untuk pemukiman (tanah kampung) yang tidak dimasukkan dalam konsesi yang berada di pinggiran kebun.

3. Hak untuk melintasi jalan-jalan di areal konsesi yang menghubungkan satu kampung ke kampung lain.

4. Hak untuk tetap dipertahankannya fasilitas-fasilitas umum yang ada di dalam areal konsesi seperti pekuburan, sungai-sungai dan pantai termasuk hak untuk mengambil material-material berupa pasir dan batu yang dipergunakan masyarakat untuk bangunan.

5. Hak untuk tetap dipeliharanya pohon tualang tempat lebah bersarang agar masyarakar dapat mengambil madunya. (Mahadi, $1978: 68$ ).

Keadaan itu berlangsung sampai pada masa pendudukan Jepang dan pasca kemerdekaan. Perubahan keadaan itu terlihat nyata setelah Pemerintah Indonesia mengeluarkan Undang undang No. 86 Tahun 1958 tentang Nasionalisasi Perusahaan-perusahaan Milik Belanda. Atas nama nasionalisasi, hak-hak masyarakat hukum adat Deli beralih menjadi perusahaan milik negara. Sultan/Kepala Masyarakat Adat bersama masyarakatnya kehilangan "sumber ekonomi". Rakyat tak lagi dapat bercocok tanam pada masa bera yaitu tenggang waktu tanah tidak dimanfaatkan pihak perkebunan untuk bertanam tembakau atau "dihutankan" dengan rotasi 7 tahun. (Masa bera adalah masa rotasi 5 atau 7 tahun tanah dihutankan setelah tembakau di panen. Hal ini dilakukan untuk menjaga kesuburan tanah dan menghindari gangguan hama tanaman sehingga pada masa bera tersebut, tanah dihutankan dan penghutanannya dapat berupa tanaman palawija untuk masa 1 tahun tanam yang diserahkan kepada masyarakat adat).

Hilangnya hak-hak masyarakat adat Melayu Sumatera Timur menimbulkan banyak konflik. Diantara sekian banyak konflik itu, ada yang dibawa kedalam sidang peradilan formal namun tidak jarang pula putusan sidang itu menimbulkan konflik yang baru lagi di tengahtengah masyarakat. Beberapa kasus yang digelar di sidang peradilan formal dapat dilihat pada tabel berikut ini.

Tabel 1 
Putusan Pengadilan atas Pengambilan Lahan Tidak Sah

\begin{tabular}{|c|c|c|c|c|c|}
\hline No & $\begin{array}{l}\text { Pengadilan } \\
\text { Negeri }\end{array}$ & Tanggal & $\begin{array}{l}\text { Jumlah } \\
\text { Pengambil } \\
\text { Tanah }\end{array}$ & Keputusan & Kebun \\
\hline 1. & Medan & $12-07-1955$ & 11 orang & $\begin{array}{l}1 \text { bulan hukuman } \\
\text { penjara bersyarat dengan } \\
\text { waktu percobaan } 6 \text { bulan }\end{array}$ & $\begin{array}{l}\text { Bandar } \\
\text { Klippa }\end{array}$ \\
\hline 2. & Medan & 12-07-1955 & 7 orang & $\begin{array}{l}1 \text { minggu hukuman } \\
\text { penjara bersyarat dengan } \\
\text { waktu percobaan } 6 \text { bulan }\end{array}$ & Saentis \\
\hline 3. & Medan & 25-10-1955 & 72 orang & $\begin{array}{l}\text { Tahanan } 5 \text { hari (potong } \\
\text { waktu ditahan } 5 \text { hari) } \\
\text { dan pengosongan tanah } \\
\text { yang dikuasai }\end{array}$ & $\begin{array}{l}\text { Bandar } \\
\text { Klippa }\end{array}$ \\
\hline 4. & Medan & $10-11-1955$ & 110 orang & Denda Rp. 10,-- & Helvetia \\
\hline 5. & Lubuk Pakam & $---10-1955$ & 180 orang & $\begin{array}{l}\text { Hukuman bersyarat } 10 \\
\text { hari dengan waktu } \\
\text { pencobaan } 3 \text { bulan }\end{array}$ & Batang Kwis \\
\hline 6. & Medan & $22-11-955$ & 155 orang & $\begin{array}{l}6 \text { hari hukuman penjara } \\
\text { dengan potong waktu di } \\
\text { tahan enam hari }\end{array}$ & $\begin{array}{l}\text { Bandar } \\
\text { Klippa }\end{array}$ \\
\hline
\end{tabular}

Sumber : Edy Ikhsan, Antan Patah Lesungpun Hilang : Kontestasi Normatif dan Pergeseran Hak Tanah Komunal dalam Perspektif Sosio-Legal (Studi pada Etnis Melayu Deli di Sumatera Utara), Disertasi, Program Studi Doktor (S3) Ilmu Hukum Fakultas Hukum Universitas Sumatera Utara, Medan, 2012, hal. 218.

Konflik itupun sampai hari ini belum berakhir. Bahkan pada saat pemerintah mengambil kebijakan untuk mengeluarkan lahan Hak Guna Usaha PT. Perkebunan Nusantara II (eks konsesi Sultan Deli dan masyarakat hukum adatnya) seluas 5.873 Ha pada tahun 2002 dan 2004 - Surat Keputusan Kepala BPN No. 42/HGU/BPN/2002, tanggal 22 Nopember 2002, Surat Keputusan Kepala BPN No. 43/HGU/BPN/2002, tanggal 22 Nopember 2002, Surat Keputusan Kepala BPN No. 44/HGU/BPN/2002, tanggal 22 Nopember 2002, serta Surat Keputusan Kepala BPN No.10/HGU/BPN/2004 tanggal 6 Pebruari 2004 - telah menjadikan lahan tersebut menjadi "ladang pembantaian" (the killing field). (Pemberitaan di media massa lokal memaparkan tentang berbagai-bagai kejadian peristiwa berdarah dan pembunuhan di atas lahan tersebut karena banyaknya klaim masyarakat atas lahan itu yang disponsori oleh para mafia tanah dan organisasi kemasyarakatan sosial dan bahkan oleh para pejabat yang telah ditentukan porsinya jika perjuangan mereka berhasil untuk mendapatkan lahan-lahan tersebut. Lihat lebih lanjut tulisan Herdensi Adnin, Lahan Eks HGU PTPN II dan Masalah Konflik Agraria di 
Sumatera Utara, Sintesa, 20 Januari 2012, 8000 Ha lahan Eks HGU Beralih ke Developer, Harian Sumut Pos tanggal 27 April 2013, Perebutan Lahan PTPN II Deli Serdang Makan Korban Jiwa, Medan Pos, 12 November 2014, Usai Bentrok Perebutan Lahan Eks HGU PTPN II, Polisi Periksa Lima Saksi, Sumut Pos, 2 Agustus 2012).

Saat ini, masyarakat adat Melayu Deli tidak memiliki hak apapun lagi di atas lahanlahan tersebut. Padahal pada masa awal konsesi itu diberikan, Masyarakat Adat Deli memiliki hak atas sumber daya alam tempat mereka lahir, bermain, tumbuh dan dibesarkan. Lahan-lahan yang dikonsesikan itu sesungguhnya adalah lahan-lahan milik masyarakat hukum adat Melayu Deli. Mengapa nasionalisasi kehilangan arah dan menjadi alat penjajahan baru bagi masyarakat hukum adat ? Dampak seperti apa yang timbul akibat kebijakan nasionalisasi itu ? Paling tidak, inilah yang akan coba dicarikan jawabannya di dalam tulisan ini sekaligus melatar belakangi tulisan ini dimunculkan.

\section{B. Metode Penelitian}

Tulisan ini mengacu pada pemaduan pilihan metode non doktrinal riset dan doktrinal riset yang digunakan sekaligus. Oleh karena itu metode penelitian ini keluar dari tradisi yang selama ini telah mendominasi model penelitian hukum. Metode campuran (mixed methods) dimaksudkan untuk menghilangkan dikotomi antara penelitian kuantitatif dengan penelitian kualitatif, menghilangkan dikotomi antara penelitian juridis normatif dengan sosiologis empiris. Dengan demikian, penelitian ini akan banyak meminjam model-model penelitian yang dipakai dalam ilmu-ilmu sosial dan sejarah. (Esin Orucu dan Elspeth Attwooll \& Sean Coyle, 1996).

Tulisan ini menjelaskan pilihan politik hukum nasionalisasi perusahaan Belanda yang kemudian menjadi Perusahaan Negara melalui Undang-undang No. 86 Tahun 1958 adalah pilihan politik hukum yang keliru untuk kasus Masyarakat Adat Deli. Tulisan ini bersumber pada bahan hukum primer berupa peraturan perundang-undangan termasuk Surat Keputusan Kepala Badan Pertanahan Nasional dan berbagai surat yang diterbitkan oleh Pemerintah Provinsi Sumatera Utara. Di samping itu, tulisan ini juga didasarkan pada pengamatan langsung terhadap berbagai peristiwa yang terjadi di atas lahan-lahan eks konsesi Masyarakat Adat Deli tersebut (sebagai data primer). Pemberitaan-pemberitaan di media massa sebagai data sekunder juga digunakan dalam tulisan ini dengan menggunakan metode analisis isi (content analysis). Kesimpulan dan berbagai temuan adalah merupakan hasil dari analisis kualitatif dari data-data yang diperoleh terutama dengan membandingkan hak-hak Masyarakat Adat Deli masa lalu yang 
tertera dalam Akte Konsesi dengan hak-hak mereka yang ada pada hari ini pasca pemerintah menerapkan kebijakan nasionalisasi.

\section{Hasil Penelitian dan Pembahasan}

\section{Nasionalisasi : Politik Hukum yang Keliru}

Terbitnya HGU atas tanah oleh Badan Pertanahan Nasional, mempengaruhi pula pola penguasaan tanah oleh pihak PTPN II. Dapatlah dibayangkan bagaimana interaksi pola-pola penguasaan tanah di atas areal PTPN II tersebut oleh masyarakat, yang masing-masing mengacu pada konsepsi penguasaan tanah yang berbeda. Yang berlangsung adalah pola hubungan kemasyarakatan yang rawan konflik, yang terjadi karena adanya konflik pada sistem dan konsep hukum yang berbeda. Secara internal juridis dapat dipastikan sebenarnya terdapat konflik hukum.

Konflik hukum ini berpangkal pada kebijakan nasionalisasi yang merupkan langkah politis yang diambil oleh Pemerintah pada tahun 1958 melalui Undang-undang No. 86 Tahun 1958. Kebijakan nasionalisasi yang semula dimaksudkan untuk mengambil alih aset-aset milik Kolonial Belanda untuk dijadikan aset nasional untuk dan atas nama "kemerdekaan" ternyata di kemudian hari adalah taburan benih yang membuahkan banyak persoalan. Nasionalisasi haruslah diakui sebagai sebuah peristiwa politik yang banyak menyembunyikan dan mengubur berbagai-bagai hak masyarakat hukum Adat Deli sebagai bahagian dari Masyarakat Adat Deli sebagai subyek hak atas tanah-tanah perkebunan yang dinasionalisasi itu.

Bila dirujuk pada bentuk hubungan hukum antara masyarakat Hukum Adat Deli sebagai bahagian dari Masyarakat Adat Deli dengan onderneming Belanda, hubungan hukum yang lahir di antara keduanya adalah dalam bentuk perikatan perdata. Perikatan Perdata murni antara masyarakat hukum Adat Deli sebagai bahagian dari Masyarakat Adat Deli sebagai pemilik tanah dengan onderneming Belanda sebagai pihak yang akan memanfaatkan tanah itu untuk membuka usaha perkebunan. Sebuah perikatan perdata untuk membuka usaha bisnis dalam bidang perkebunan. Pihak Onderneming Belanda tidak tampil sebagai subyek hukum negara atau subyek hukum dalam bentjuk badan hukum publik, tgapi tampil sebagai subyek hukum dalam bentuk badan hukum privatm, yakni dalam bentuk badan hukum poerseroan (Naamluze vennotschaap) seperti NV. Deli Maatschappij, NV Arensberg Maaschappij, NV. Deli Rubber Maatschappij dan lain-lain. Sementara di sisi lain tanah-tanah perkebunan itu adalah milik rakyat atau masyarakat pribumi, yakni masyarakat Hukum Adat Deli sebagai bahagian dari 
Masyarakat Adat Deli. Oleh karena itu dapat dipastikan dalil-dalil yang digunakan dalam proses politik nasionalisasi itu adalah keliru. Tidak ada unsur imperialisme dalam hubungan kontrak konsesi antara pihak pengusaha Onderneming Perkebunan dengan pihak Masyarakat Hukum Adat Deli selaku pemilik tanah yang diwakili oleh Kesultanan Deli (Sultan Deli dan Datuq 4 suku serta orang-orang besarnya). Dalil-dalil nasionalisasi yang keliru itu dalam "kacamata hukum" dimulai dari pengabaian asas-asas hukum. Pengabaian terhadap tata nilai yang merupakan "grundnorm” meminjam, istilah Kelsen (2007).

Dalam kaitannya dengan nasionalisasi itu dapat dikatakan bahwa : jika pengalihan terhadap perusahaan perkebunan itu dilakukan dengan peperangan sekalipun, sehingga kebunkebun itu diposisikan sebagai "harta pampasan perang" maka negara sebagai pemenang perang harus memilah hak siapa saja yang ada di atas harta hasil rampasan perang itu. Akan tetapi untuk kasus pengalihan perkebunan asing milik pengusaha Belanda di atas lahan masyarakat hukum adat Deli itu, tanah-tanah dan kebun itu bukanlah harta pampasan perang. Tanah-tanah itu milik masyarakat pribumi dan kebun serta bangunan yang ada di atasnya adalah milik perusahaan yang secara kebetulan adalah warga negara Belanda. Mereka bukan Koloni, mereka bukan imperialism, mereka datang dengan membawa modal, membawa keahlian, membayar penyewaan tanah, memberikan hak bercocok tanam kepada masyarakat adat di atas lahan sat tidak ditanami tembakau, membayar upah buruh dan karyawan. Mereka adalah pembisnis murni dan Kesultanan Deli dan masyarakat hukum adatnya adalah pemilik tanah dengan hak-hak kepemilikan yang asli, yang original tidak bergantung pada Pemerintah Kolonial di Belanda maupun dengan Pemerintah Kolonial Belanda.

Pandangan ini menguatkan anggapan bahwa, perikatan antara Perusahaan perkebunan milik pengusaha asing Belanda dengan Masyarakat Hukum Adat Deli, adalah perikatan perdata murni. Sebuah perjanjian yang tunduk pada prinsip-prinsip atau asas-asas hukum perjanjian. Terdapat sejumlah hak dan kewajiban para pihak yang dituangkan dalam akta konsesi di berbagai perkebunan di wilayah Kerajaan Negeri Deli dan Kesultanan di Sumatera Timur lainnya ketika itu.

Berdasarkan uraian di atas dapat dipastikan bahwa tanah tidak dapat dijadikan obyek nasionalisasi, oleh karena tanah itu adalah milik Masyarakat Adat Deli. Masyarakat bukanlah orang asing karena itu tanah yang dimilikinya bukan juga tanah milik asing, sedangkan pemaknaan nasionalisasi adalah menasionalkan milik asing untuk dijadikan milik nasional. Undang-undang Nasionalisasi No. 86 Tahun 1958 juga menegaskan yang dinasionalisasi adalah 
perusahaan Belanda. Tentu saja yang harus dinasionalisasi itu adalah asset-asset yang terdaftar dalam asset perusahaan Belanda tersebut yaitu asset yang terdaftar dalam Daftar Asset Deli Maatschapij, Arrensbug Maatschapij atau Deli Rubber Maatschapij. Asset berupa tanah tidak terdaftar dalam buku asset perusahaan-perusahaan Belanda tersebut kecuali disebut terdaftar sebagai hak sewa. Hak sewa atau hak konsesi tentu mempunyai masa berlakunya. Ketika masa berlaku itu berakhir, maka tanah-tanah Masyarakat Adat Deli yang terdapat di wilayah-wilayah konsesi itu haruslah dikembalikan. Jika kemudian secara politis perusahaan itu harus dinasionalisasi, maka hak sewa itu dapat diteruskan (vested rights). Artinya, perusahaan nasional tetap mempunyai hak konsesi (hak sewa), bukan lantas mengkonversinya menjadi Hak Guna Usaha yang 100\% menghilangkan hak-hak Masyarakat Adat Deli. Jika kemudian hak itu dialihkan kepada pihak ketiga, yang dilakukan oleh perusahaan nasional (PT. Perkebunan Nusantara 2 Persero) maka tindakan itupun bertentangan dengan hukum karena pihak PT. Perkebunan Nusantara 2 (Persero) adalah sebagai penerus hak konsesi dari perusahaan perkebunan Belanda. Jika pengalihan oleh PT. Perkebunan Nusantara 2 (Persero) kepada pihak ketiga itu telah terjadi, maka pengalihan itu haruslah dinyatakan batal demi hukum karena pihak yang mengalihkan bukanlah pihak yang berhak atau berwenang (beschikking bevoegdheid) dan pengalihan semacam itu bertentangan dengan pasal 584 KUH Perdata. Pihak PT. Perkebunan Nusantara 2 (Persero) telah melampaui kewenangannya sebagaimana tersirat dalam asas nemo plus juris. Tanah-tanah yang dialihkan itu adalah tanah-tanah yang dikonsesikan di wilayahwilayah Masyarakat Adat Deli, oleh karena itu tanah itu harus dikembalikan kepada masyarakat yang bersangkutan. Tidak boleh dialihkan kepada pihak ketiga dengan cara yang bertentangan dengan hukum.

Tabel 2

Konsesi Kesultanan Deli Dengan Deli Maatscappij (1869 - 1929)

\begin{tabular}{|c|c|c|c|c|}
\hline Naam Der Concessie & $\begin{array}{c}\text { Naam V.D. } \\
\text { Onderneming of } \\
\text { Toegevoegd Bij De } \\
\text { Onderneming }\end{array}$ & $\begin{array}{c}\text { Te } \\
\text { verbou } \\
\text { wrs } \\
\text { Product }\end{array}$ & $\begin{array}{l}\text { Afloop Van } \\
\text { Het Contract }\end{array}$ & $\begin{array}{c}\text { Opper Vlante } \\
\text { Van Het } \\
\text { Contract }\end{array}$ \\
\hline $\begin{array}{ll}\text { 1. } & \text { Gamborg } \\
\text { (Petersburg) } \\
\text { 2. Helvetia } \\
\text { 3. Soengei Agoel } \\
\text { 4. Project-Pematang } \\
\text { Kwis } \\
\text { 5. Soengei Poetih } \\
\end{array}$ & $\begin{array}{l}\text { Sampali } \\
\text { Helvetia } \\
\text { Helvetia } \\
\text { Bandar Klippa } \\
\text { Mariendal } \\
\text { Rotterdam A } \\
\text { Rotterdam B } \\
\text { Mariendal } \\
\end{array}$ & $\begin{array}{c}\text { Tabak } \\
" \\
" \\
"\end{array}$ & $\begin{array}{l}\text { 17 Dec } 1956 \\
\text { 15 Oct } 1957 \\
6 \text { April } 1942 \\
\text { 18 Mei } 1950 \\
\text { 25 Juni } 1952 \\
\text { 29 Juni } 1950 \\
\text { 3 Dec } 1944 \\
\end{array}$ & $\begin{array}{l}\text { Bouw. } \\
930 \\
3617 \\
558) 6995 \\
1437) \\
570 \\
1308 \\
1100\end{array}$ \\
\hline
\end{tabular}




\begin{tabular}{|c|c|c|c|c|}
\hline $\begin{array}{l}\text { 6. Soengei Sikambing } \\
\text { 7. Polonia } \\
\text { 8. Mabar-Deli Toewa } \\
\text { 9. Soeka Piring } \\
\text { 10. Boven } \\
\text { Kw.Betimoes of } \\
\text { Botoe Sanggehan } \\
\text { 11. Charlottenburg } \\
\text { 12. Belawan } \\
\text { 13. Toentoengan } \\
\text { 14. Kotta Lambaroe } \\
\text { 15. Beneden Bekalla } \\
\text { 16. Saint Cyr } \\
\text { 17. Boven Bekalla } \\
\text { 18. Arnhemia } \\
\text { 19. Gambir } \\
\text { 20. Loening } \\
\text { 21. Oedjoeng Deleng } \\
\text { 22. Rimboen } \\
\text { 23. Roemah } \\
\text { Kinangkong of } \\
\text { Taboeran } \\
\text { 24. Boeloe Tjina } \\
\text { 25. Paya Bakong } \\
\text { 26. Rotterdam }\end{array}$ & $\begin{array}{l}\text { Sampali-Medan Est.- } \\
\text { Mariendal } \\
\text { Deli Toewa } \\
\text { Deli Toewa } \\
\text { Belawan Estate } \\
\text { Belawan Estate } \\
\text { Toentoengan } \\
\text { Toentoengan } \\
\text { Bekalla en Arnhemia } \\
\text { Bekala } \\
\text { Arnhemia } \\
\text { Arnhemia } \\
\text { Rimboen } \\
\text { Ged. Bij Arnhemia } \\
\text { Ged. Bij Arnhemia } \\
\text { Rimboen } \\
\text { Ged. Bj Toentoengan } \\
\text { Ged. Bij Rimboen } \\
\text { Bocloc Tjina en ged. } \\
\text { Bij Paya Bakong } \\
\text { Paya Bakong en ged. } \\
\text { Bij Rotterdam B } \\
\text { Rotterdam A en } \\
\text { Rotterdam B }\end{array}$ & " & $\begin{array}{r}\text { 18 Sept } 1956 \\
29 \text { Des } 1960 \\
\text { 25 Juli } 1960 \\
27 \text { Aug } 1955 \\
\text { 21 Nov } 1954 \\
\text { 19 Mei } 1956 \\
27 \text { Aug } 1955 \\
\text { 21 Nov } 1954 \\
\text { 2 Feb } 1956 \\
\text { 24 Juni } 1955 \\
\text { 22 Aug } 1956 \\
\text { 22 Aug } 1956 \\
\text { 20 Aug } 1961 \\
\text { 23 Oct } 1955 \\
\text { 31 Oct } 1960 \\
\text { 24 Dec } 1957 \\
\text { 15 Sept } 1948\end{array}$ & $\begin{array}{l}4950 \text { ) } 10180 \\
5230) \\
5066 \\
1977 \\
1600 \\
2210 \\
1500 \\
4240 \\
2400 \\
2864 \\
2836,8 \\
1618 \\
2387 \\
1957 \\
3665 \\
4352,88 \\
1254,31 \\
3720\end{array}$ \\
\hline
\end{tabular}

Sumber: John Anderson, Mission to the East Coast of Sumatra in 1823, Kuala Lumpur Singapore, Oxford University Press, London New York, 1971.

Berdasarkan tabel tersebut di atas, dapat dipahami bahwa tanah Deli, tanah yang terikat pada akte konsesi itu adalah tanah-tanah masyarakat hukum adat yang tunduk pada hubungan hukum perjanjian, yakni perjanjian yang bersumber dari perikatan. Tidak terlihat bahwa penguasaan tanah-tanah perkebunan itu didasarkan pada proses kolonialisasi. Tidak juga proses pengalihan tanah-tanah masyarakat hukum adat Deli itu kepada perusahaan perkebunan Belanda yang merupakan perusahaan milik Kerajaan Negeri Belanda atau Kerajaan Hindia Belanda, akan tetapi kebun-kebun itu diusahakan atas dasar perikatan hukum perdata murni. Oleh karena itu didalam kontrak-kontrak konsesi itu tertera dengan jelas tempat-tempat atau lokasi-lokasi lahan yang dikonsesikan. Tertera juga dengan jelas luasan lahan yang dikonsesikan serta tenggang waktu lamanya konsesi sebagaimana terlihat pada tabel di bawah ini. 
Tabel 3

Penegasan Tentang Lokasi Luas Tanah dan Jangka Waktu Konsesi

\begin{tabular}{|c|c|c|c|c|c|}
\hline \multirow[b]{2}{*}{$\begin{array}{c}\text { Nama } \\
\text { Konsesi }\end{array}$} & \multicolumn{2}{|c|}{ Luas Tanah } & \multirow{2}{*}{$\begin{array}{c}\text { Masa } \\
\text { Konsesi }\end{array}$} & \multirow{2}{*}{$\begin{array}{l}\text { Eksperasi/ } \\
\text { (habis masa } \\
\text { kons) }\end{array}$} & \multirow[b]{2}{*}{ Keterangan } \\
\hline & $\begin{array}{c}\text { Bahu/bou } \\
\text { w }\end{array}$ & Hektar & & & \\
\hline Mandi Angin & 1136 & $\ldots$ & 25 thn & 31 Des 1931 & \\
\hline Terjun & 1096 & 777 & 12 thn & 1 Des 1937 & \\
\hline Sei Beras & 5436 & $\ldots$ & 63 thn & 3 Mei 1952 & \\
\hline Klumpang & 4910 & $\ldots$ & 65 thn & 3 Mei 1954 & \\
\hline $\begin{array}{l}\text { Klambir } \\
\text { Lima }\end{array}$ & 331 & $\ldots$ & 63 thn & 10 Apr 1954 & \\
\hline $\begin{array}{l}\text { Bandar } \\
\text { Bejambu }\end{array}$ & 3128 & 2220 & 75 thn & 3 Maret 1965 & \\
\hline Naga Raja & 4317 & 2064 & 75 thn & 12 Des 1974 & \\
\hline Mabar & 2500 &.. & $\ldots$ & 28 Juli 1938 & \\
\hline Maryland & 1400 & $\ldots$ & $\ldots$ & $-"$ & \\
\hline Sampali & 210 & $\ldots$ & $\ldots$ & $-"$ - & \\
\hline Sei Krio Kiri & 106 & $\ldots$ & $\ldots$ & 18 Juli 1936 & \\
\hline Tjg. Baleh & 342 & $\ldots$ & $\ldots$ & 4 Nop 1937 & \\
\hline Germania & 560 & $\ldots$ & $\ldots$ & 5 Maret 1957 & \\
\hline $\begin{array}{l}\text { Sunggal A \& } \\
\text { B }\end{array}$ & 248 & $\ldots$ & $\cdots$ & 22 Sept 1957 & \\
\hline Saentis & 1050 & $\ldots$ & $\ldots$ & 13 Maret 1949 & \\
\hline $\begin{array}{l}\text { Sebrang } \\
\text { (Percut) }\end{array}$ & 1430 & $\cdots$ & $\cdots$ & 30 Juni 1960 & $\begin{array}{l}\text { Dahulu } \\
\text { diperhitungkan satu }\end{array}$ \\
\hline Sei Merah & & $\ldots$ & $\ldots$ & 16 Sept 1960 & Bouw $/$ bahu $=50004$ \\
\hline Sei Simujur & 4116,30 & $\ldots$ & $\ldots$ & 31 Agust 1960 & $\begin{array}{l}\text { persegi, yl. } \\
\text { Panjang }=50 \text { depa } \\
\text { Lebar }=40 \mathrm{depa} \\
1 \text { depa }=6 \mathrm{kaki}\end{array}$ \\
\hline
\end{tabular}

Sumber: John Anderson, Mission to the East Coast of Sumatra in 1823, Kuala Lumpur Singapore, Oxford University Press, London New York, 1971.

Berdasarkan data di atas, semakin jelaslah bahwa hubungan hukum yang terjadi antara perkebunan asing Belanda dengan Kesultanan Deli adalah hubungan hukum keperdataan bukan hubungan hukum publik. Tabel di atas juga membuktikan bahwa tanah yang dikonsesikan itu adalah tanah ulayat masyarakat hukum adat Melayu Deli. Tanah-tanah yang dikonsesikan itu, diberi batas waktu, artinya tidak tunduk pada konsep wilayah jajahan. Tidak juga tunduk pada hukum-hukum pemerintah negara jajahan (Pemerintah Belanda dan Pemerintah Hindian Belanda), tapi tunduk pada "perjanjian yang dituangkan dalam Akte Konsesi”. Dengan begitu sebenarnya "Nasionalisasi" yang dilkakukan oleh pemerintah Indonesia pasca Kemerdekaan 
melalui UU No.68 Tahun 1958 adalah sebuah kekeliruan. Apalgi Nasionalisasi itu "merampok" meminjam istilah Edy Ikhsan (2013) tanah-tanah masyarakat hukum adat Deli.

Mengenai hal itu dapat saya jelaskan : jika-jika tanah-tanah itu berpindah menjadi milik Perkebunan Negara, melalui proses politik dan proes politik itu telah mengambil alih pula hakhak masyarakat hukum Adat Deli, inilah awal dari konflik tanah perkebunan di wilayah ini. Tidak hanya di Deli, tapi di Sumatera Timur. Masyarakat Hukum Adat Deli telah kehilangan haknya. Beruntunglah masyarakat yang tinggal di kaki gunung Sibayak dan Sinabung, yang tinggal di Pinggiran Dana Toba, yang berdomisili di pinggir-pinggir pantai di sepanjang pesisir Sumatera Timur, karena wilayah itu tidak dikonsesikan. Kalau dulu wilayah itu dikonsesikan, maka sekarang wilayah itu akan menjadi milik Perusahaan Perkebunan Negara atau Badan Usaha Milik Negara, untuk dan atas nama nasionalisasi. Oleh karena itu saya tegaskan, bahwa proses politik dapat saja dilakukan, tapi jangan "membunuh" anak bangsa sendiri, jangan "menghisap" hak-hak anak bangsa sendiri, jangan "merampok" hak-hak anak bangsa sendiri. Tak ada hak apapun yang diterima oleh Masyarakat Hukum Adat Deli dan Kesultanan Deli, dari kontrak perkebunan yang dibuat oleh kesultanan Deli dengan Onderneming Perkebunan pasca Nasionalisasi, pada hal kebun-kebun itu saat ini telah menyumbangkan devisa negara yang tidak sedikit. Proses politik yang dilakukan melalui kebijakan Nasionalisasi tidak hanya memperlihatkan pelanggaran hak yang kasat mata, tapi juga pelanggaran atau pengabaian halhal yang sangat prinsipil, yakni pengabaian terhadap etika, moral dan asas-asas kehidupan berbangsa dan bernegara dan berbagai asas hukum lainnya. Negara kemudian menjadi “penjajah" atas bangsanya sendiri. (OK. Saidin, 2002);

Dalam Harian Republika saya pernah menulis :

Ketidaktegasan peraturan perundang-undangan dan penerapan kebijakan yang setengah hati terhadap pengakuan hak ulayat menyebabkan konflik pertanahan di atas lahan HGU PTPN II menjadi terus berkelanjutan hingga hari ini. Rakyat di satu sisi diminta untuk membuktikan adanya hak ulayat sedangkan pihak perkebunan di pihak lain membuktikan alas haknya melalui HGU. Sudah barang tentu keduanya tidak akan bisa dipertemukan karena di satu sisi penguasaan hak ulayat berdasarkan hukum adat didasarkan pada ipso facto sedangkan penguasaan HGU oleh pihak PTPN didasarkan pada ipso jure. Hak ulayat masyarakat hukum adat bukan tidak ada akan tetapi dibuat menjadi tidak ada.

Peraturan perundang-undangan-lah yang membuat hak ulayat masyarakat Melayu Deli itu menjadi tidak ada. Padahal sebelumnya pada masa perkebunan itu diusahai oleh perusahaan perkebunan asing justru terdapat pengakuan terhadap hak ulayat yakni dengan memberikan hak 
untuk bercocok tanam kepada masyarakat Hukum Adat Melayu Deli yang kemudian dikenal dengan tanah jaluran. Pihak Kesultanan Deli sendiri sebagai kepala masyarakat adat beserta kedatukan dan orang-orang besarnya juga mendapat "royalty" dari hasil perkebunan itu yang secara tegas dituangkan dalam klausule-klausule yang berisikan hak dan kewajiban masingmasing pihak. Akan tetapi justru setelah kemerdekaan hak-hak semacam itu tidak pernah lagi diberikan kepada masyarakat hukum adat dan kepada pihak Kesultanan Deli selaku subyek hak yang mengikatkan diri dengan pihak pengusaha perkebunan warga negara Belanda tersebut.

Ada semacam gugatan dari pihak Kesultanan Deli terhadap perusahaan perkebunan negara yang tidak menghargai hak-hak masyarakat hukum adat Kesultanan Deli sebagaimana diungkapkan oleh Bachtiar Dja'far (2002), pernah mengatakan :

Belanda saja lebih bisa menghargai hak-hak masyarakat Melayu, dibandingkan dengan Pemerintah Indonesia. Pemerintah Indonesia lebih sadis dari pemerintah Kolonial Belanda dalam menyikapi hak-hak puak Melayu di atas lahan perkebunan.

Dalam kontrak konsesi, pihak perkebunan atau perusahaan perkebunan asing itu telah mereduksi berbagai asas-asas hukum kontrak, dan pihak Masyarakat hukum Adat Deli mereduksi pula sejumlah asas hukum adat antara lain asas pemisahan horizontal. Asas-asas inilah yang dalam proses nasionalisasi dan hukum-hukum ikutannya yang lahir di kemudian hari yang diabaikan oleh berbagai pihak, mulai dari pihak BPN sampai pada pihak legislatif, eksekutif dan bahkan judikatif.

\section{Tanah Konsesi Sebagai Hak Masyarakat Adat Deli}

Nasionalisasi telah membuahkan banyak konflik. Bagaimanapun juga, tanah yang dikonsesikan bukanlah milik perusahaan asing, tetapi milik masyarakat hukum adat. Tanah yang dikonsesikan itu adalah merupakan satu-satunya sumber kehidupan masyarakat hukum adat pada waktu itu. (Afnawi Nuh, 1998). Kisah perjalanan John Anderson kami turunkan dalam tulisan ini adalah sebagai bukti untuk menguatkan pandangan kami bahwa tanah lahan yang dikonsesikan kepada perkebunan Belanda. John Anderson, seorang anggota East India Company's Service di Penang W.E. Philips untuk melakukan sesuatu kunjungan "politicocommercial". (John Anderson, $1971: \mathrm{v})$.

Sesuai dengan perintah yang diterima John Anderson dari atasannya, sehabis perjalanannya, ia membuat laporan mengenai berbagai-bagai masalah yang dilihatnya, didengarnya dalam daerah-daerah yang dikunjunginya. Di daerah-daerah yang dikunjunginya, 
didapatkannya masyarakat yang menyandarkan kehidupannya pada hasil-hasil hutan di atas lahan yang kelak dikemudian hari dikonsesikan kepada perusahaan perkebunan Belanda. Lokasi tanah atau hutan yang dikonsesikan kepada Onderneming Belanda tempat masyarakat mengambil hasil hutan itu dapat dilihat pada tabel berikut ini :

Tabel 4

Lokasi-lokasi Tanah-tanah Kesultanan Deli

yang Dikonsesikan Kepada Onderneming Belanda

\begin{tabular}{|c|c|c|c|}
\hline No & Daerah & Penghasilan & Keterangan \\
\hline 1. & $\begin{array}{l}\text { Soonghal } \\
\text { (Sunggal) }\end{array}$ & & $\begin{array}{l}\text { Tidak kurang dari } \\
20.000 \text { Batak-Karo } \\
\text { asyik bercocok tanam }\end{array}$ \\
\hline 2. & $\begin{array}{l}\text { Bulu Cina } \\
\text { (daerah Deli) }\end{array}$ & $\begin{array}{ll}\text { 1. Lada } \\
\text { 2. Gambir }\end{array}$ & $\begin{array}{l}15.000 \text { pikul/tahun eksport } \\
\text { ke Pinang dan Malaka }\end{array}$ \\
\hline 3. & $\begin{array}{l}\text { Deli } \\
\text { (Deli) }\end{array}$ & $\begin{array}{l}\text { 1. Lada } \\
\text { 2. Padi } \\
\text { 3. Tembakau } \\
\text { 4. Kelapa dan } \\
\text { Pinang } \\
\text { 5. Kayu } \\
\text { 6. Gambir }\end{array}$ & $\begin{array}{l}\text { Meidan (Medan) } \\
\text { Berpenduduk } 200 \text { orang } \\
\text { Penduduk (Batak Karo) } \\
\pm 5.000 \text { orang } \\
\text { Hasil } 26.000 \text { pikul dalam tahun } 1822 \\
\text { Cukup untuk makanan sendiri } \\
\text { Dieksport, ditanam, dipelihara dan dipanen } \\
\text { secara teratur } \\
\text { The plantations of cocoa-nuts and betel-nuts are } \\
\text { very extensive. } \\
\text { Bermacam-macam. Dieksport ke Pinang. } \\
\text { Dieksport. Penduduk Melayu berjumlah } \pm 7.000 \\
\text { orang }\end{array}$ \\
\hline 4. & $\begin{array}{l}\text { Perchoot } \\
\text { (Percut) }\end{array}$ & Lada & Di bawah Deli \\
\hline 5. & Sungei Tuan & Lada & Di bawah Deli \\
\hline 6. & Serdang & Lada & Ekspor ke Pinang, Malacca \\
\hline
\end{tabular}

Sumber: John Anderson, Mission to the East Coast of Sumatra in 1823, Kuala Lumpur Singapore, Oxford University Press, London New York, 1971.

Pertanyaan yang dapat diajukan dari data yang dikemukakan oleh John Anderson adalah, di atas lahan manakah lada, rotan, gambir, padi, kayu abar, kayu lakur, tembakau, kelapa dan pinang serta sagu itu tumbuh ? Jawabnya adalah : hasil-hasil hutan itu tumbuh di atas lahan masyarakat hukum adat Deli. Perjalanan Anderson pada tahun 1823 itu jauh sebelum Nienhuys menginjakkan kakinya di tanah Deli (1 Mei 1863). Kelak setelah Nienhuys datang, lahan tanah ulayat itu dikemudian hari oleh Sultan Makmun Al-Rasyid dan Kesultanan Melayu Sumatera 13 | Yustisia. Vol. 4 No. 1 Januari - April 2015 
Timur lainnya dikonsesikan kepada pengusaha orderneming yang tertuang dalam akte konsesi. (Akte konsesi tunduk pada hukum perikatan (Buku III KUH Perdata). Akte konsesi yang dibuat pada tahun 1863 itu tidak tunduk pada Buku II KUH Perdata yang diberlakukan pada tahun 1848 di daerah jajahan. Oleh karena itu akte konsesi tidak pernah dapat disejajarkan dengan hakhak yang diatur dalam Buku II KUH Perdata semisal hak guna usaha (erfach recht). Kekeliruan nasionalisasi yang kemudian mengkonversi hak konsesi menjadi hak guna usaha adalah sebuah kekeliruan yang tidak saja bertentangan dengan asas-asas hukum benda tetapi juga bertentangan dengan hak asasi manusia yakni perlindungan terhadap hak milik dan hak-hak komunal masyarakat hukum adat).

Akte konsesi ini adalah merupakan hubungan keperdataan. Hubungan antara pemilik tanah (Sultan Deli) dengan pihak yang akan menyewa tanah untuk mendirikan usaha dalam bidang perkebunan (Onderneming Belanda : Deli Maatchapij, Deli Rubber Maatchapij, Arrensburg Maatchapij dan lain-lain). Bentuk hubungan hukum antara keduanya adalah dalam bentuk hukum perikatan yang tunduk pada Buku III KUH Perdata. (Pada saat kontrak ditandatangani, KUH Perdata telah dinyatakan berlaku di wilayah Hindia Belanda, tetapi instrument yang digunakan oleh keduanya adalah instrument hukum perikatan bukan instrument hukum benda yang diatur dalam Buku II KUH Perdata). Hak yang lahir dari hubungan hukum itu adalah hak perorangan (person recht) bukan hak kebendaan dalam arti zaakenrecht. (Mariam Darus, 2010 : 43). Bandingkan juga dengan Sri Soedewi Masjchoen Sofwan, (1981 : 24).

Memang di Kesultanan Deli ada beberapa bentuk akta yang dikeluarkan yang juga sifatnya melahirkan hak kebendaan yang dikenal dengan grant Sultan - Grant Sultan Deli pertama kali diterbitkan pada tahun 1909), yakni Grant No. 1 bertarikh 1 Januari 1909 berlokasi di Desa Junainah, Kecamatan Deli Tua, Kabupaten Deli Serdang, atas nama Tengku Redhwan dan Encik Puan Nemah. Lebih lanjut lihat Surat Sultan Deli Azmy Perkasa Alam Alhaj No. 027.2/IM-SD/VII/1996 tanggal 6 Juli 1996 dan Surat Sultan Deli Otteman Mahmud Perkasa Alam No. 23/IM-SD/2003 tanggal 28 April 2003 perihal Pengantar Risalah Edaran Tentang Keberadaan Surat-surat Penting dan Arsip Kesultanan Deli (sesuai keterangan kami di Polresta Belawan No. 24.6/IM-SD/2011 perihal Penjelasan Kesultanan Deli Tentang Keabsahan Grant Sultan tanggal 19 Mei 2011) - Grant Sultan ini adalah bentuk dari kepemilikan hak atas tanah secara individu dan grant itu tidak diterbitkan di atas tanah konsesi. Ada hak yang diterbitkan di atas tanah konsesi yang disebut dengan eigendom verponding. Eigendom verponding ini adalah hak yang diletakkan di atas hak konsesi. Eigendom verponding ini termasuk dalam kategori 
perjanjian ekor (perjanjian buntut) yang induknya adalah perjanjian konsesi (yang dituangkan dalam akta konsesi). Pada masa perkebunan tembakau dan perkebunan-perkebunan lainnya telah berhasil dibangun oleh pengusaha-pengusaha perkebunan Belanda timbul keinginan para pengusaha perkebunan itu untuk mendirikan usaha transportasi seperti kereta api. Pada waktu itu berkumpullah para pengusaha itu untuk mendirikan unit usaha transportasi kereta api. Oleh karena tanah-tanah yang digunakan untuk pembangunan usaha transportasi kereta api itu terikat dalam konsesi maka perusahaan kereta api yang didirikan itu memohon kepada perusahaan perkebunan untuk memakai tanah tersebut. Pihak perkebunan kemudian meminta ijin kepada Sultan Deli (dan sultan-sultan lain di Sumatera Timur) untuk pemakaian tanah tersebut untuk jalur kereta api dan pembangunan rumah-rumah karyawan dan stasiun-stasiun. Kesultanan Deli kemudian memberikan ijin kepada perusahaan kereta api tersebut yang waktu itu adalah Deli Spoorweg Maatchapij (DSM) untuk memakai tanah yang terikat dengan konsesi perkebunan tersebut. Misalnya dalam surat Sultan Deli tanggal 30 September 1882 yang ditujukan kepada Deli Spoorweg Maatchapij atas permintaannya untuk pemakaian tanah Sultan Deli yang dikonsesikan kepada Deli Maatchapij sebagaimana yang termaktub dalam Mabar Deli Toewa Kontrak tanggal 11 Juni 1870 atau bertepatan dengan 11 Rabiul Awal 1287, antara Kesultanan Deli dan Deli Maatschappij, yang dibuat dan ditandatangani di depan Notaris W.J.M Michielsen, tertanggal 17 November 1870. Dalam suratnya tersebut Sultan Deli mengatakan, "tidak berkeberatan untuk pemanfaatan tanah itu guna kepentingan pembangunan sarana dan prasarana kereta api dan terhadap tanah-tanah yang tidak dipergunakan lagi oleh Deli Matschappij harus dikembalikan kepada Kesultanan Deli”.

Menurut catatan yang dikemukakan oleh Labberton, persyaratan yang ditetapkan dalam kontrak konsesi yang harus dipenuhi adalah :

1. Kontrak itu harus dilakukan setelah ada persetujuan dari pemerintah (Hindia Belanda) setempat.

2. Sejauh mungkin obyek tanah yang dikontrakkan itu dikelola dan diurus sendiri, (dalam hal ini dikelola dan diurus sendiri oleh Onderneming Belanda).

3. Tidak boleh dialihkan tanpa persetujuan para pihak dan tanpa ada didaftar atau diketahui oleh Pemerintah Hindia Belanda.

4. Keberadaan penduduk yang berdiam di tanah konsesi tidak dibenarkan (tanah konsesi sudah bersih dari klaim kepemilikan pribadi/tidak ada kepemilikan dalam bentuk grand sultan). 
5. Para buruh yang dipekerjakan harus diperoleh dengan sukarela (tidak boleh dipaksa seseorang untuk menjadi buruh). (Labberton, K, van Hinlopen, 1903 : 43).

Jadi dapat dipastikan tanah-tanah yang dikonsesikan oleh Kesultanan Deli dengan perusahaan perkebunan Belanda bebas dari kepemilikan secara pribadi. - Walaupun dikemudian hari hal ini menjadi problema yang semakin mengacaukan oleh karena banyaknya grant-grant sultan yang terbit di atas lahan-lahan konsesi itu. Hal ini terjadi karena grant Sultan yang terdaftar di Kesultanan Deli pada suatu waktu diserahkan kepada Kantor Pertanahan Kota Medan terdiri atas 14 buku namun buku-buku tersebut tidak lagi utuh tersimpan di Kantor Pertanahan dimaksud sehingga grant-grant yang terdaftar itu sulit untuk dilacak. Apalagi tidak semua grant sultan terdaftar dalam buku tersebut. Pada saat setelah Revolusi Sosial tahun 1946, keluarga Kesultanan Deli sebahagian meninggalkan istana Maimoon dan sebahagian lagi tinggal di istana. Blanko grant Sultan masih terdapat di istana yang kemudian banyak dimanfaatkan oleh pihak-pihak lain dikemudian hari untuk mengklaim tanah-tanah yang ada di wilayah Kesultanan Deli. Sayangnya klaim itu sampai pada lokasi tanah konsesi yang sesungguhnya disana tidak lagi terdapat grant Sultan dengan kata lain di atas tanah konsesi tidak terdapat grant Sultan sebagai bukti kepemilikan secara pribadi (privat). - Penegasan tentang hal ini dikemukakan juga oleh A.P. Parlindungan, yang menyatakan bahwa di atas tanah konsesi tidak terbit grant Sultan sebagai bukti kepemilikan hak pribadi. (Pendapat ini disampaikan oleh A.P. Parlindungan pada saat memberikan kesaksian ahli dalam persidangan gugatan Perdata Gugatan antara Sultan Deli terhadap pengembang Polonia). Mengenai lokasi-lokasi tanah yang dikonsesikan, sebelumnya adalah merupakan tanah masyarakat hukum adat Deli tempat mereka mengambil hasil hutan. Sepanjang diperlukan untuk uraian ini disadurkan tulisan yang berasal dari laporan John Anderson sebagaimana tertera pada tabel di bawah ini :

Tabel 5

Hasil Hutan Sebagai Sumber Penghidupan Masyarakat Hukum Adat Melayu Sumatera Timur Sebelum Dikonsesikan Kepada Onderneming Belanda

\begin{tabular}{|r|l|l|ll|}
\hline No & \multicolumn{1}{|c|}{ Daerah } & \multicolumn{1}{|c|}{ Penghasilan } & \multicolumn{1}{|c|}{ Keterangan } \\
\hline 1. & Langkat & 1. Lada & Berkualitas baik & Eksport \\
& & & Amerika/Eropa & \\
& & 2. Rotan & 20.000 pikul/tahun & \\
& & 3. Gambir & & \\
& & 4. Padi & Dieksport ke Cina & \\
& & 5. Kayu Abar & & \\
& & 6. Kayu Lakur & & \\
\hline
\end{tabular}




\begin{tabular}{|c|c|c|c|}
\hline 2. & $\begin{array}{l}\text { Soonghal } \\
\text { (Sunggal) }\end{array}$ & & $\begin{array}{l}\text { Tidak kurang dari } \\
20.000 \text { Batak-Karo } \\
\text { asyik bercocok tanam }\end{array}$ \\
\hline 3. & $\begin{array}{l}\text { Bulu Cina } \\
\text { (daerah Deli) }\end{array}$ & $\begin{array}{l}\text { 3. Lada } \\
\text { 4. Gambir }\end{array}$ & $\begin{array}{l}15.000 \text { pikul/tahun } \\
\text { eksport } \\
\text { ke Pinang dan Malaka }\end{array}$ \\
\hline 4. & $\begin{array}{l}\text { Deli } \\
\text { (Deli) }\end{array}$ & $\begin{array}{l}\text { 7. Lada } \\
\text { 8. Padi } \\
\text { 9. Tembakau } \\
\text { 10. Kelapa dan Pinang } \\
\text { 11. Kayu } \\
\text { 12. Gambir }\end{array}$ & $\begin{array}{l}\text { Meidan (Medan) } \\
\text { Berpenduduk } 200 \text { orang } \\
\text { Penduduk (Batak Karo) } \\
\pm 5.000 \text { orang } \\
\text { Hasil } 26.000 \text { pikul dalam } \\
\text { tahun } 1822 \\
\text { Cukup untuk makanan } \\
\text { sendiri } \\
\text { Dieksport, ditanam, } \\
\text { dipelihara dan dipanen } \\
\text { secara teratur } \\
\text { The plantations of cocoa- } \\
\text { nuts and betel-nuts are } \\
\text { very extensive. } \\
\text { Bermacam-macam. } \\
\text { Dieksport ke Pinang. } \\
\text { Dieksport. Penduduk } \\
\text { Melayu berjumlah } \pm \\
7.000 \text { orang }\end{array}$ \\
\hline 5. & Perchoot (Percut) & Lada & Di bawah Deli \\
\hline 6. & Sungei Tuan & Lada & Di bawah Deli \\
\hline 7. & Serdang & Lada & $\begin{array}{lll}\text { Ekspor ke } & \text { Pinang, } \\
\text { Malacca } & & \\
\end{array}$ \\
\hline 8. & Batu Bara & Rotan & $\begin{array}{l}\text { Penduduk Melayu } \\
\text { berjumlah 10.000 }\end{array}$ \\
\hline 9. & Asahan & $\begin{array}{l}\text { 1. Kayu } \\
\text { 2. Padi } \\
\text { 3. Lada }\end{array}$ & Diekspor \\
\hline 10. & Kwalooh & Rotan & Diekspor \\
\hline 11. & $\begin{array}{l}\text { Beelah } \\
\text { (Bilah) }\end{array}$ & Rotan & Diekspor \\
\hline 12. & Panci & Rotan & Diekspor \\
\hline 13. & Siak & $\begin{array}{l}\text { 1. Gambir } \\
\text { 2. Sago }\end{array}$ & Diekspor \\
\hline
\end{tabular}

Sumber: John Anderson, Mission to the East Coast of Sumatra in 1823, Kuala Lumpur Singapore, Oxford University Press, London New York, 1971.

Pertanyaan yang dapat diajukan dari data yang dikemukakan oleh John Anderson (1971) adalah, di atas lahan manakah lada, rotan, gambir, padi, kayu abar, kayu lakur, tembakau, kelapa 
dan pinang serta sago itu tumbuh ?. Hasil-hasil bumi itu tumbuh di atas lahan Masyarakat Adat Deli. Itulah sebabnya dikemudian hari, sekalipun tanah itu dikonsesikan kepada pengusaha perkebunan Belanda, hak-hak masyarakat hukum adat tetap diberikan yaitu berupa hak untuk bercocok tanam pada saat tanah tidak ditanami tembakau (masa penghutanan = masa bera) yang kemudian hari dikenal sebagai tanah jaluran. Rakyat yang diberi hak untuk bercocok tanam itu adalah rakyat yang berasal dari masyarakat hukum adat Deli atau masyarakat yang telah lama bermukim dan tinggal di pinggiran perkebunan itu. Mereka diberi hak untuk bercocok tanam selama satu musim tanam dan akan berpindah-pindah mengikuti rotasi penanaman tembakau yang dihutankan selama 5-7 tahun itu. Hak-hak ini kemudian hilang begitu saja pasca lahirnya Undang-undang No. 86 Tahun 1958 tentang Nasionalisasi Perusahaan-perusahaan Milik Belanda.

\section{Dampak dari Undang-undang Nasionalisasi No. 86 Tahun 1958}

Nasionalisasi merupakan kebijakan politik Negara Kesatuan Republik Indonesia pasca revolusi kemerdekaan tahun 1945. Tujuannya sangat ambisius yakni membebaskan Indonesia dari pengaruh ekonomi asing terutama dari Negeri Belanda. memperkuat keamanan dan pertahanan Republik Indonesia dari intervensi luar.Lazimnya dalam fenomena revolusi sebagai fenomena yang tidak biasa tentu saja Indonesia pada saat revolusi belum memiliki konsep perekonomian nasional guna menggantikan model ekonomi kolonial Belanda. Ada dua konsep yang ditawarkan yakni Pertama, Para Investor luar tetap dibiarkan untuk melakukan kegiatan investasi di Indonesia karena pada masa transisi ini mereka masih tetap diperlukan guna menjaga stabilitas dan pertumbuhan ekonomi, namun jika ada perusahaan asing yang terbukti melakukan kegiatan yang dapat dikategorikan kejahatan kapitalisme seperti mengeksploitasi kekayaan sumberdaya alam Indonesia maka terhadap perusahaan ini dapat dilakukan tindakan nasionalisasi. Kedua, Seluruh perusahaan milik investor asing disita dan dijadikan Perusahaan Negara guna membangun sistem perekonomian nasional yang terintegrasi yang berbasis pada kekuatan sendiri. Kedua pandangan utama tersebut tidak dengan sendirinya saling berlawanan,bahkan keduanya dikembangkan dengan hasil yang cukup baik selama periode demokrasi parlementer. Kendati demikian, terdapat ketegangan antara keduanya,karena perjuangan untuk memupus dominasi ekonomi asing bertentangan dengan investasi besarbesaran yang diperlukan untuk membangun industri-industri baru. (Bondan Kanumoyoso, 2001 : 3). Untuk meredakan ketegangan diantara kedua pandangan tersebut muncullah gagasan yang 
memberikan peranan utama kepada Negara untuk menentukan keputusannya. (Chalmers, Ian, 1996 : 100). Dalam proses Nasionalisasi ini Indonesia ingin menunjukkan bahwa dengan jiwa patriotisme dan nasionalisme yang kuat kedaulatan ekonomi harus berada di tangan bangsa sendiri dengan pengelolaan perusahaan tanpa ketergantungan kepada bangsa lain. Disisi lain kondisi ekonomi yang semakin parah juga merupakan penyebab dilakukannnya nasionalisasi. Secara formal Pemerintah Indonesia menjelaskan :

"The reasons Indonesia embarked upon these measures were not, however, solely, economic. Psychological factor also played an importand role. For centuries Indonesia had been discriminated against by the colonial power.The people had been deprived of the land wich, under adat law,was to be cultivated by the village community, and both men and women had been forced to work for Dutch enterprises under inhuman conditions.(The Bremen Tobacco Case, 1960 : 18).

Meskipun tujuan nasionalisasi terkesan ingin menerapkan kedaulatan ekonomi diatas kaki sendiri tanpa campur tangan pihak asing namun sebenarnya tujuan utamanya adalah membebaskan Irian barat (Papua Barat) dari cengkeraman Belanda dan menjadi bagian dari wilayah Indonesia. Konsideran Undang-Undang Nasionalisasi 1958 dengan tegas menyebutkan bahwa tindakan nasionalisasi perusahaan milik Belanda yang berada di Wilayah Republik Indonesia menjadi milik Negara dalam rangka perjuangan pembebasan Irian barat adalah sesuai dengan kebijaksanaan pembatalan Konferensi Meja Bundar.

Bersamaan dengan itu hubungan Indonesia dengan Belanda semakin kritis setelah Belanda menolak untuk melanjutkan perundingan penyerahan Irian Barat kepada Indonesia sesuai dengan amanat Konferensi Meja Bundar. Disamping itu gagalnya PBB menyetujui sebuah resolusi yang disiapkan untuk mengatasi masalah Irian serta adanya upaya pembunuhan terhadap Presiden Republik Indonesia Soekarno, telah membangkitkan semangat nasionalisme bangsa Indonesia dan menimbulkan gerakan kebencian (anti) kepada Belanda dengan melakukan upaya pengambil-alihan Perusahaan dan kantor-kantor dimana aktivitas perdagangan dilakukan. Pengambil alihan ini merupakan konkritisasi dari pemikiran dari berbagai tokoh nasional Indonesia yang memberikan pandangan tentang perlunya perubahan struktur ekonomi Indonesia dari ketergantungan terhadap asing menjadi mandiri dengan berbasis pada ekonomi nasional atau nasionalisme ekonomi. Perumusan tentang aspirasi tersebut secara garis besar mencakup tiga aspek utama, Pertama, suatu perekonomian yang beragam dan stabil dalam arti ditiadakannya ketergantungan yang besar terhadap ekspor bahan mentah. Kedua, suatu perekonomian yang berkembang dan makmur atau pembangunan ekonomi, Ketiga, suatu 
perekonomian pribumi, yang berarti dominasi ekonomi Barat dan etnis Cina harus dialihkan kepada orang-orang Indonesia. (Muhaimin, Yahya A, 1990 : 22). Ketiga aspek diatas secara ideologis menunjukkan keinginan yang kuat bangsa Indonesia untuk dapat berdiri diatas kaki sendiri (berdikari), jargon yang selalu didengung-dengungkan oleh Presiden Republik Indonesia Soekarno dalam setiap pidato politiknya, Namun keinginan ini tidak dengan mudah diterapkan karena kondisi perekonomian Indonesia saat itu masih didominasi perusahaan-perusahaan milik belanda. Dalam pernyataan yang menentukan mengenai kebijakan ekonomi luar negeri, pada bulan Februari 1950 Presiden Soekarno menyatakan bahwa nasionalisasi merupakan soal bagi masa depan yang jauh di muka. Dan penciptaan perekonomian nasional terlebih dahulu menuntut mobilisasi semua sumber modal,dari dalam maupun luar negeri. (Sutter, Jhon O., 1959 : 1107-1108). Pada tanggal 3 Mei 1956, Presiden Republik Indonesia Soekarno dengan persetujuan Dewan Perwakilan Rakyat Republik Indonesia telah mengesahkan Undang-undang Nomor 13 tahun 1956 tentang Pembatalan Hubungan Indonesia-Nederland berdasarkan Perjanjian Meja Bundar. Pasal 9 Undang-undang ini menyebutkan Undang-undang ini dapat disebut Undang-undang Pembatalan Konperensi Meja Bundar seluruhnya. Dasar pertimbangan dibatalkannya Perjanjian Meja bundar adalah karena Irian Barat sebagai bagian mutlak dari wilayah Republik Indonesia masih juga diduduki oleh Pemerintah Kerajaan Belanda walaupun semestinya telah lama harus diserahkan kepada Pemerintah Republik Indonesia yang penuh berhak atas bagian mutlak itu. Disisi lain usaha dari Pemerintah Indonesia untuk mendapatkan persetujuan kedaulatan penuh atas wilayah Irian Barat dari Pemerintah Kerajaan Belanda yang dilakukan dalam beberapa perundingan selalu kandas karena ketidak sediaan Kerajaan Belanda dan oleh karenanya Pemerintah Republik Indonesia memutuskan Pembatalan Perjanjian Meja Bundar adalah jalan yang adil dan pantas. Pada Pasal 6 Undang-undang ini disebutkan "Hubungan antara Republik Indonesia dan Kerajaan Nedeland (Belanda) selanjutnya adalah hubungan yang lazim antara Negara-negara yang berdaulat penuh berdasarkan hubungan Hukum Internasional". Maksudnya Pembatalan Perjanjian Meja Bundar tidak menyebabkan hubungan diplomatik Indonesia-Belanda menjadi terputus. Hal-hal yang berkaitan dengan kepentingan bangsa Belanda yang ada di wilayah Republik Indonesia akan diperlakukan secara normatif, seperti Hak, konsesi, izin dan cara menjalankan perusahaan Belanda akan diindahkan jika tidak bertentangan dengan kepentingan pembangunan Negara (vide pasal 7 Undang-undang R.I. Nomor 13 tahun 1956). Menindak lanjuti pelaksanaan Undang-undang ini pada tanggal 31 Desember 1956 Pemerintah Indonesia memberlakukan Undang-undang Nomor 29 tahun 1956 
tentang Peraturan-Peraturan Dan Tindakan-Tindakan Mengenai Tanah-Tanah Perkebunan.Dasar pertimbangan lahirnya Undang-undang ini adalah perlunya diadakan peraturan-peraturan dan diambil tindakan-tindakan terhadap tanah-tanah guna perusahaan kebun, yang kini keadaan perusahaannya sedemikian rupa hingga tidak mungkin diusahakan kembali secara layak atau yang kini belum diusahakan atau tidak diusahakan kembali sebagaimana mestinya. Tanah-tanah perkebunan yang termasuk dalam Undang-undang ini adalah tanah-tanah yang penguasaanya diberikan dengan hak erfpacht. Pasal 1 Undang-undang ini menyebutkan Hak-hak erfpacht guna perusahaan kebun yang pada waktu berlakunya Undang-undang telah habis masa berlakunya atau di dalam satu tahun akan habis masa waktunya, sedang keadaan perusahaannya adalah sedemikian rupa hingga menurut pertimbangan Menteri Pertanian tidak mungkin diusahakan lagi secara layak,tidak akan diperpanjang atau diperbaharui. Menurut Undang-undang ini,hak erfpacht dapat dibatalkan apabila menurt pertimbangan Menteri Pertanian perusahaan pemegang hak tidak mengusahakan tanah secara layak atau karena alasan-alasan yang tidak dapat dibenarkan belum diusahakan kembali oleh perusahaan.Ketentuan Undang-undang ini hanya menyebut hak erfpacht sedangkan pengaturan mengenai hak-hak konsesi perkebunan secara khusus tidak ada. Pemberian hak erfpacht dilakukan oleh Pemerintah Hindia Belanda berdasarkan ketentuan domein verklaring, berdasar Undang-undang Agraria tahun 1870 (Agrarisch Wet 1870) dan Domein Verklaring untuk Sumatera (Stb.1874-94f) yang objek tanahnya berasal dari domein Pemerintah Hindia Belanda. Domein Verklaring sebagaimana diatur dalam Staatblad 1870 No.118 Pasal 1 menyatakan : "Semua tanah yang tidak ada bukti kepemilikannya adalah eigendom atau milik Negara. Yang dimaksud Negara dalam hal ini adalah Pemerintah Hindia Belanda. Domein atas tanah tersebut oleh Pemerintah Belanda dapat diserahkan kepada orang Belanda atau yang dipersamakan dengan memberlakukan ketentuan hukum Belanda terhadap hak atas tanah yang diberikan seperti hak erfpacht dan sebagainya. Terhadap tanah-tanah yang berada diluar domein Negara seperti yang dikuasai oleh penduduk Bumi Putera, Pemerintah Hindia Belanda tetap mengakuinya dengan kedudukan sebagai tanah adat atau tanah pemerintahan swapraja. Pengaturan tanah adat bagi penduduk Bumi Putera tunduk pada ketentuan hukum adatnya. Akibatnya terjadilah dualisme hukum yakni Untuk bangsa Belanda dan yang dipersamakan berlaku hukum belanda dan bagi penduduk bumiputera berlaku hukum adat.Di Deli, konsesi diberikan yang Sultan Deli kepada perusahaan perkebunan Belanda dibuat berdasarkan perjanjian yang objek tanahnya adalah milik masyarakat komunal hukum adat Deli. 
Kepada semua pemilik/perusahaan-perusahaan Belanda yang berada di Sumatera Utara agar mentaati perintah ini. Bagi Warga Negara Belanda yang ada di Sumatera Utara juga dikeluarkan Peraturan Penguasa Militer tentang Pembatasan Kebebasan Bergerak serta kewajiban untuk melaporkan diri apabila akan bepergian dari dan kembali ke Sumatera Utara. Situasi ini diberlakukan dengan mengingat Keputusan Pejabat Yang Mulia Presiden Republik Indonesia Nomor 40 tahun 1957 tentang berlakunya Keadaan Perang di Seluruh Wilayah Indonesia. Meskipun terjadi pengambil alihan perusahaan-perusahaan milik Belanda namun prosesnya dilakukan dengan hati-hati agar tidak merugikan kepentingan nasional dan kesinambungan operasional perusahaan dapat terus berlangsung. Ungkapan ini terlihat dengan dikeluarkannya Amanat Panglima T\&T-I yang menyatakan:

Perusahaan-perusahaan Belanda yang ada di Indonesia pada umumnya mempunyai functie economi dan social yang bagi kehidupan rakyat dan negara sangat penting artinya. Oleh sebab itu rakyat dan Negara sangat berkepentingan akan kelanjutan dan kesempurnaan jalannya perusahaan tersebut. Lepas dari persoalan siapa yang menjadi pemilik perusahaan-perusahaan tersebut adalah kewajiban Pemerintah,demi keselamatan Rakyat,menjamin lancarnya perjalanan perusahaan-perusahaan itu.Harus dicegah dengan sekuat tenaga perbuatan merusak atau mengganggu perjalanan perusahaan.Penguasa Militer mengharapkan baik dari pihak buruh maupun dari pihak direksi perusahaan pengertian sedalam-dalamnya tentang ini.Jangan hendaknya ada orang atau golongan yang akan mempergunakan kesempatan guna kepentingan diri sendiri atau golongan yang akan mempergunakan kesempatan ini guna kepentingan diri atau golongan sendiri, sehingga dengan demikian merugikan kepentingan Nasional.Persaan sentiment terhadap orang-orang Belanda supaya dikendalikan. Ingatlah bahwa tindakan-tindakan kita tidak boleh bersifat permusuhan terhadap sesame manusia.Janganlah sampai tindakan-tindakan kita melanggar dasar-dasar dari Negara kita,Yaitu Ke-Tuhanan yang Maha Esa,Peri Kemanusiaan dan lain-lain. Dari pimpinan perusahaan bangsa Belanda kami harapkan supaya mematuhi segala perintah dan petunjuk yang diberikan oleh Penguasa Militer c.q.oarang atau badan yang ditunjuknya. Supaya menghindarkan perbuatan-perbuatan yang merugikan perusahaan disini,umpamanya memindahkan hak milik/kekayaan perusahaan kepada pihak ketiga atau keluar negeri secara bersembunyi. Perbuatan-perbuatan serupa itu akan berakibat buruk bagi yang bersangkutan.

Apabila diamati secara sepintas Amanat Panglima T\&T-I ini, peran militer hanyalah sebagai pengawas agar operasional perusahaan Belanda yang diambil alih dapat berjalan sebagaimana mestinya dan untuk menghindari kerugian perusahaan. Namun dalam kenyataannya lebih dari itu yakni ikut serta dalam menentukan struktur jabatan di perusahaan,seperti kalimat berikut:

"Pergeseran-pergeseran dalam jabatan pimpinan sedapat mungkin dihindarkan.Kalaupun ini harus terjadi,hal ini hanya dapat dilakukan dengan persetujuan Penguasa Militer c.q.orang atau badan yang ditunjuk oleh Penguasa Militer". 
Dengan makin luasnya peran militer dalam menentukan struktur perusahaan pada akhirnya akan menentukan berbagai hal yang berkaitan dengan kebijakan manajemen perusahaan.Perlahan namun pasti fenomena "Militer Berbisnis" menjadi menggejala dan menjadi sumber keuangan baru baik bagi militer pusat maupun di daerah. Peran ini semakin menguat setelah Kepala Staf Angkatan Darat pada tanggal 13 Desember 1957 menerbitkan larangan pengambil alihan perusahaan Belanda tanpa sepengetahuan militer serta melakukan pengawasan terhadap perusahaan-yang diambil alih tersebut. Namun dalam praktek pengelolaan perusahaan tersebut diserahkan kepada pihak lain yang mempunyai kedekatan dengan pihak militer. Secara teoritis apabila sektor penting seperti ekonomi di nasionalisasi akan meningkat maka tingkat kemakmuran dan kesejahteraan rakyat. Kelihatannya menjalankan perusahaan itu mudah namun ternyata realitasnya memerlukan ketrampilan dari tenaga ahli di bidang manajemen,operasional dan lain-lainnya.Inilah yang tidak sepenuhnya dimiliki bangsa Indonesia ketika semua bangsa asing yang menguasai perusahaan itu sebelum di nasionalisasi. Akibatnya banyak perusahaan yang di nasionalisasi menjadi Badan Usaha Milik Negara menjadi bangkrut karena faktor gagal di bidang manajemen. Penilaian tentang latar belakang dan proses nasionalisasi atau pengambilalihan perusahaan-perusahaan milik Belanda dapat dilihat dari dua sudut pandang yaitu: Pertama, Peristiwa pengambilalihan perusahaanperusahaan Belanda merupakan kejadian yang sama sekali tidak direncanakan sebelumnya. Pandangan ini diperkuat oleh tiadanya suatu program pemerintah yang teratur dalam pelaksanaan pengambialihan. (Bondan Kanumoyoso, 2001 : 69). Kedua, Pemerintah berada di belakang aksi pengambilalihan tersebut. Suatu skenario telah dirancang, dimana rakyat yang marah merebut fasilitas yang kemudian ditempatkan oleh pemerintah dalam penjagaan perlindungan. Pandangan ini diperkuat oleh pernyataan Presiden Soekarno, bahwa pengambilalihan tersebut diprakarsai oleh dirinya sendiri. (Bondan Kanumoyoso, 2001). Kedua pandangan diatas terkesan berbeda tapi intinya sama yaitu pengambilaliahn perusahanperusahaan Belanda tanpa persetujuan pemiliknya. Meskipun kemudian dilegitimasi dengan undang-undang tetap saja perbuatan tersebut dapat dikategorikan sebagai perbuatan melanggar hukum karena prosesnya tidak melalui prosedur yang benar dan oleh orang yang tidak mempunyai kewenangan berhak (Bechikking bevoegdheid).

Dampak yang ditimbulkannya dikemudian hari, tetap saja mengundang masyarakat hukum adat Deli yang diikuti oleh kelompok masyarakat lainnya untuk melakukan 
penyerobotan penggarapan dan bahkan tindakan memanipulasi surat-surat alas hak untuk mendapatkan sebahagian dari lahan konsesi yang dinasionalisasi tersebut. Pasca nasionalisasi, pihak perkebunan yang dalam kasus ini adalah PT. Perkebunan Nusantara 2 (Persero) telah juga mengeluarkan sebahagian lahannya untuk masyarakat akan tetapi hal itu tidak menghentikan aktivitas penggarapan dan penyerobotan tanah lahan PT. Perkebunan Nusantara 2 (Persero) itu di kemudian hari termasuk pada saat sebagian besar lahan itu dikeluarkan dari penguasaan Hak Guna Usaha PT. Perkebunan Nusantara 2 (Persero) pasca perpanjangan Hak Guna Usaha setelah tahun 2000 .

Penyerobotan tanah, penggarapan tanah, pembakaran bangsal tembakau, demonstrasi masyarakat dan lain-lain kian hari kian meluas. Di pihak lain, pihak perkebunan melepas tanah kepada para pengembang (Devestasi berkali-kali dilakukan oleh PT (Persero) Perkebunan Nusantara II seperti di Jalan Pancing Medan Estate, di Laut Dendang, menyusul di atas lahan 300 Ha di Helvetia, 75 Ha di Sampali, Kantor Besar Peninggalan Nienhuys di Jalan Putri Hijau dan di tempat lain di Tanjung Morawa, Binjai dan Langkat), organisasi kemasyarakatan dan organisasi masyarakat adat. Kalangan birokrasi memainkan perannya sendiri untuk mengeruk keuntungan pribadi hingga muncul kasus di tahun 2002, menyebabkan Dirut PTPN II ketika itu harus mendekam di penjara yang berujung pada penggantian Direksi. Namun demikian hukum tak pernah bisa benar-benar tegak, sekalipun perkara-perkara tentang itu digelar di pengadilan.

Era reformasi membuat situasi semakin runyam. Perkelahian, pembunuhan, pembakaran rumah dan gubuk-gubuk petani penggarap kerap kali terjadi. Di atas lahan perkebunan yang oleh pihak perkebunan negara itu diklaim sebagai HGU berdasarkan UUPA No. 5 Tahun 1960, berdiri bangunan-bangunan, mulai dari gubuk, rumah semi permanen, rumah permanen, sampai pada mesjid dan gereja, oleh masyarakat yang mengklaim tanahnya sebagai tanah adat.

Konflikpun mulai terbuka, manakala di atas lahan itu tumbuh padi dan jagung yang siap untuk dipanen, pada saat itu pula pihak PTPN II mendatangkan traktor lengkap dengan aparat pengamanan mentraktor tanaman dan membongkar paksa gubuk dan rumah-rumah serta bangunan illegal itu. Bagi masyarakat itu hanya ancaman sesaat, berikutnya tanam lagi dan membangun lagi di tempat-tempat lain lagi di atas lahan yang tadinya 250.000 Ha kini tinggal 47.000 Ha.

Pemerintah Daerah Sumatera Utara membentuk tim untuk tim penyelesaian tanah itu yang dikenal dengan nama Tim B-Plus pada penghujung tahun 1998, tapi sampai tim itu usai 
melakukan tugasnya melahirkan berbagai surat keputusan namun lebih dari 13 tahun, tak pernah memperlihatkan hasilnya, konflik terus berlangsung. Pihak pejabat pembuat akta tanah, mulai dari lurah, kepala desa, camat sampai Badan Pertanahan Nasional (di Tingkat I dan II) daerah mengeluarkan banyak surat sebagai alas hak, tak teridentifikasi asli atau palsu, legal atau illegal. Yang pasti di atas lahan yang sama berdiri kompleks perumahan mewah, pabrik-pabrik, rumah toko, lapangan golf milik swasta dan lain-lain, membuat kecemburuan sosial semakin hari semakin menyeruak.

Kini masyarakat di sekitarnya, melihat tanah itu "bak anak ayam ditaburi beras" semua mematuk, dan menelannya, sekali-sekali mereka saling menginjak. Perjalanan sejarah tanah ulayat dan masyarakat hukum adat telah mencatat beberapa hal yang membuktikan adanya pertentangan antara masyarakat hukum adat dengan pihak perkebunan. (T. Lukman Sinar, 1980) - (Perang Sunggal di zaman Kolonial, tiga perkara pidana yang diajukan di Pengadilan Negeri Binjai dan Pengadilan Negeri Medan (1968, 1980, 1981) membuktikan sekaligus merupakan manifestasi dari pertentangan antara pihak perkebunan dengan sejumlah warga yang menamakan dirinya Rakyat Penunggu). - Selain itu menyusutnya lahan perkebunan tembakau yang sangat tajam (250.000 ha pada periode Kolonial (Mahadi, 1978 : 23) menjadi hanya 15.000 ha di tahun 1994 (Harian Kompas, 1994 : 9) menjadi satu latar pokok runcingnya pertentangan di antara perkebunan dan rakyat penunggu.

Lebih satu abad sudah tatkala hak-hak rakyat penunggu atas tanah jaluran tercantum untuk pertama kalinya dalam contoh akta konsesi (1884) maka telah banyak kejadian yang terjadi, (terekam maupun tidak) di seputar itu. Di tengah-tengah itu pula muncul petani penggarap, Pemegang KRPT sebagai "Saingan Baru" rakyat penunggu. Dengan berbagai cara dan langkah yang mereka tempuh mereka itu ada yang mendapat tempat di hati pihak perkebunan, pemerintah dan rakyat penunggu namun ada juga yang tidak. Tetapi kesemua ini menimbulkan konflik baru sebagai akibat dari pemaknaan yang makin meluas tentang siapa sesungguhnya subyek hak ulayat. (Saidin, $1986: 53$ ).

Mereka yang menamakan dirinya Badan Kesejahteraan Masyarakat Adat Deli (BKMAD), Forum Pembebasan Tanah Ulayat Masyarakat Melayu Sumatera Timur (Forum Peta Umat), Kesatuan Masyarakat Hukum Adat Serdang (KMHAS), Masyarakat Hukum Adat Deli (MAHADI), para pengusaha, yayasan dan peroranganpun banyak melakukan klaim liar terhadap lahan eks tanah konsesi tersebut. Hingga akhirnya Pemerintah Provinsi Sumatera Utara membentuk Tim Penyelesaian Tanah yang disebut Tim B-Plus. 
Dalam perjalanannya Tim B-Plus juga tidak berjalan mulus dalam arti dapat menyelesaikan tugas-tugasnya sesuai apa yang dikehendaki rakyat yakni menyelesaikan konflik pertanahan antara pihak PTPN II dengan masyarakat yang mengklaim tanah tersebut sebagai tanah ulayat, tanah suguhan, tanah milik dan lain-lain sebagainya. (Saidin, 2002 : 45).

Keberadaan Tim B-Plus sendiri mendapat kritikan baik dari pihak Perkebunan (PTPN), Badan Perjuangan Rakyat Penunggu Indonesia (BPRPI), Kesultanan Deli, Pemangku Adat Serdang dan Langkat, Badan Kesejahteraan Masyarakat Adat Deli (BKMAD), Forum Pembebasan Tanah Ulayat Masyarakat Melayu Sumatera Timur (Forum Peta Umat), para penggarap, Kesatuan Masyarakat Hukum Adat Serdang (KMHAS), Masyarakat Hukum Adat Deli (MAHADI), masyarakat secara perorangan dan kelembagaan (yayasan) dan lain-lain, oleh karena Tim B-Plus sendiri diduga melakukan "penyimpangan" yakni turut "memprakarsai" pelepasan tanah-tanah tersebut kepada pihak ketiga.

Para camat dan notaris Pejabat Pembuat Akta Tanah (PPAT)-pun setelah mendapat sepotong surat dari lurah menerbitkan berbagai "alas hak" yang baru, yang kesemua itu menambah kekeruhan bagi penyelesaian konflik tanah yang dimaksudkan. Dalam saat yang sama pihak PTPN II juga memprakarsai pelepasan tanah-tanah tersebut kepada pihak ketiga dengan rekomendasi Pemerintah Kabupaten dan Pemerintah Provinsi.

Keadaan semakin keruh, manakala masyarakat secara membabi buta, menebangi tanaman di atas lahan perkebunan tersebut, membangun gubuk, rumah, mesjid dan gereja. Pembangunan rumah-rumah ibadah ini adalah sebagai tameng agar pihak-pihak lain, termasuk pihak penguasa dan aparat penegak hukum tidak berlaku semena-mena atas mereka yang menguasai tanah-tanah itu secara illegal. (Penghancuran rumah-rumah ibadah yang dibangun di atas lahan-lahan yang illegal itu akan dengan mudah memicu konflik yang bernuansa SARA (Suku, Agama, Ras dan Antargolongan). Strategi itu kelihatannya berhasil dilakukan oleh para penggarap illegal sekalipun rumah-rumah ibadah itu tidak berfungsi sebagaimana mestinya. Ada mesjid yang dibangun cukup luas tetapi tidak pernah terisi penuh pada saat pelaksanaan sholatsholat wajib. Demikian juga ada gereja yang dibangun tetapi tidak pernah terisi penuh pada waktu pelaksanaan ibadah ritual umat kristiani oleh karena rumah-rumah ibadah itu dibangun tidak ditengah-tengah pemukiman tetapi di tengah tanah garapan eks konsesi Masyarakat Adat Deli). Yang sangat memprihatinkan lagi adalah para penggarap itu ternyata "dimodali" oleh pihak-pihak investor yang menginginkan tanah itu dan di back up oleh oknum yang mengatas 
namakan organisasi-organisasi kemasyarakatan dan bahkan oleh oknum pemerintah dan aparat penegak hukum secara individual.

Puncaknya terjadi berbagai konflik di atas lahan konsesi Kesultanan Deli tersebut. Kekeliruannya ada pada Surat Keputusan Badan Pertanahan Nasional No. 42/HGU/BPN/2002 yang mensyaratkan tanah itu baru akan dapat diserahkan kepada nama-nama yang disebutkan dalam Surat Keputusan itu apabila telah mendapatkan ijin pelepasan asset dari Kementerian Badan Usaha Milik Negara. Padahal sesungguhnya tanah yang telah tidak lagi diperpanjang hak guna usahanya obyek tanah itu harus dikembalikan kepada penguasaan negara. Negara harus melihat kembali akte konsesi dimana yang berhak sesungguhnya adalah Kesultanan Deli sebagai penandatangan konsesi. Jika tanah tersebut harus didistribusikan kepada pihak-pihak yang telah disebutkan dalam Surat Keputusan Badan Pertanahan tersebut maka seyogyanyalah sebelum didistribusikan harus terlebih dahulu mendapat persetujuan dari pemegang alas hak yakni Kesultanan Deli bukan Kementerian Badan Usaha Milik Negara. Akibat kekeliruan ini, terjadi "perebutan besar-besaran" di atas lahan itu dan tidak jarang kemudian memakan korban. Korban yang berjatuhan di atas lahan itu dapat dilihat pada tabel berikut ini :

Tabel 6

Jumlah Korban Konflik Agraria yang melibatkan PTPN II

Dari tahun 2011-2014

\begin{tabular}{|c|c|c|c|c|}
\hline \multirow{2}{*}{ No } & \multirow{2}{*}{ Jumlah Kasus } & \multicolumn{3}{|c|}{ Kondisi Korban } \\
\cline { 3 - 5 } & & Tewas & Luka-Luka & Keriminalisasi \\
\hline 2011 & 4 & - & 21 & 7 \\
\hline 2012 & 12 & 2 & 41 & 6 \\
\hline 2013 & 14 & 3 & 56 & 14 \\
\hline 2014 & 3 & 1 & 25 & 37 \\
\hline Jumlah & 33 & 6 & 173 & 64 \\
\hline
\end{tabular}

Sumber : Kontras Sumatera Utara, 2014

Data yang diungkapkan oleh Kontras Sumatera Utara, membuktikan bahwa di atas lahan tersebut saat ini tidak lagi merupakan lahan pertanian yang hijau tetapi telah berubah menjadi ladang pembantaian (the killing field).

Agaknya Peringatan Wertheim ketika menulis "Masyarakat Indonesia Dalam Transisi" menjadi relevan untuk dikutip dalam naskah ini. Wertheim menulis sebagaimana dikutip oleh Syamsuddin Ishak sebagai berikut :

Proses yang terjadi pada masa lalu harus dipelajari dengan sangat sungguh-sungguh. Bagaimanapun, proses itu bukanlah hukum yang dapat dilepaskan yang harus diterima secara pasif oleh umat manusia. Proses itu tidak lebih dari regularitas yang hanya berlaku dalam suatu pola masyarakat, pada suatu periode tertentu. 
Sejarah manusia merupakan suatu interaksi konstan dari pengulangan dan pembaruan, pengulangan yang bisa tampak dalam pakaian yang baru dan pembaruan yang tampak untuk suatu skema pengulangan. (Syamsuddin Ishak, 2011 : 4). Lihat lebih lanjut dalam Willem Frederik Wertheim (1999 : xii).

Inilah satu-satunya cara untuk mengembalikan sumber daya alam Masyarakat Adat Deli yakni hak-hak atas tanah yang dulu pernah dikonsesikan kepada Onderneming Belanda, lalu kemudian atas nama nasionalisasi diambil alih oleh negara dan seiring dengan itu hilanglah hak-hak masyarakat.

\section{Simpulan}

1. Kebijakan nasionalisasi adalah keputusan politik negara yang semula dimaksudkan untuk menjadikan negeri ini memiliki kekuatan ekonomi yang berbasis pada kekuatan sendiri. Akan tetapi kebijakan itu telah menghilangkah hak-hak Masyarakat Adat Deli sekaligus merupakan benih yang memicu tumbuhnya konflik pertanahan di wilayah perkebunan yang berasal dari tanah konsesi tersebut. Ketika pihak perkebunan negara tersebut (sekarang PT. Perkebunan Nusantara 2 (Persero)) tidak lagi meneruskan hak sebagaimana hak yang diterima masyarakat hukum adat dari pihak perkebunan Belanda dahulu, maka bermuculanlah klaim-klaim pihak ketiga yang tidak memiliki alas hak (recht title) di atas lahan tersebut.

2. Kebijakan nasionalisasi yang merupakan keputusan politik negara telah memperlihatkan kekeliruannya karena menasionalkan hak-hak atas tanah milik masyarakat (bukan milik asing), padahal pemaknaan nasionalisasi adalah menasionalkan yang bukan milik nasional.

3. Konflik yang berlangsung hari ini adalah merupakan dampak dari kekeliruan pilihan politik nasionalisasi yang dilakukan oleh negara. Kini, di atas lahan konsesi Masyarakat Adat Deli itu telah berubah menjadi ladang pembantaian (the killing field.)

4. Penegasan Undang-undang Nasionalisasi yang membatasi hanya mengalihkan perusahaanperusahaan Belanda menjadi perusahaan nasional telah ditafsirkan secara meluas sehingga yang dinasionalisasi tidak hanya asset yang terdaftar dalam Daftar Asset Perusahaan Belanda akan tetapi termasuk asset yang justru milik masyarakat pribumi. Nasionalisasi telah melanggar kaedah-kaedah hukum perdata dan bahkan telah melanggar prinsip atau asas-asas hukum yang dianut dengan baik dalam sistem ilu pengetahuan hukum yaitu asas beschikking bevoegheid yang diatur dalam Pasal 584 KUH Perdata dan melanggar prinsip nemo plus juris. 
5. Perusahaan negara sebagai penerima asset pasca nasionalisasi hanyalah meneruskan hakhak konsesi itu (vested rights), sehingga ketika hak konsesi itu berakhir, maka obyek konsesi itu (tanah) harus dikembalikan kepada pemiliknya (Kesultanan dan Masyarakat Adat Deli). PT. Perkebunan Nusantara 2 (Persero) selamanya tidak pernah membuka kebun, membangun pabrik, membangun kantor dan rumah-rumah karyawan serta rumah-rumah staf. Yang membangun itu adalah perusahaan-perusahaan Belanda. Akan tetapi perusahaan Belandapun selamanya tidak pernah mempunyai hak atas tanah, mereka hanyalah penyewa (menerima konsesi dari Masyarakat Adat Deli).

\section{E. Saran}

1. Pendekatan normatif : Jika penyelesaian yang diharapkan oleh pihak Kesultanan Deli ditempuh melalui jalur hukum formal maka disarankan kepada pihak Kesultanan Deli untuk melakukan uji materil terhadap Undang-undang No. 86 tahun 1958 tentang Nasionalisasi Perusahaan-perusahaan Belanda dan selanjutnya mengajukan gugatan perdata terhadap pihak PT. Perkebunan Nusantara 2 (Persero) sebagai penerima hak berdasarkan kebijakan/politik nasionalisasi melalui Undang-undang Nasionalisasi tersebut. Gugatan perdata juga dapat dilakukan terhadap pihak Kementerian Agraria dan Tata Ruang untuk membatalkan hak guna usaha yang diterbitkan di atas tanah milik Kesultanan Deli tersebut.

2. Pendekatan sosiologis/empirik : Perlu kiranya urun rembuk, duduk bersama antara Sultan selaku kepala masyarakat adat Melayu di Sumatera Timur sebagai representasi dari masyarakat adat Melayu Sumatera Timur dengan pihak pemerintah Provinsi Sumatera Utara, Kementerian Agraria dan Tata Ruang dan pihak PT. Perkebunan Nusantara 2 (Persero) atau Kementerian Negara Badan Usaha Milik Negara guna mencapai kesepakatan bersama dalam penyelesaian konflik pertanahan yang sedang berlangsung hari ini. Dengan demikian semua pihak dapat terayomi dan hak-hak Masyarakat Adat Deli tidak terabaikan melalui pelurusan kembali makna nasionalisasi.

3. Kepada masyarakat luas hendaknya tidak mengambil langkah-langkah eugenrechting (main hakim sendiri) untuk mendapatkan hak di atas lahan konsesi yang sekarang dikuasai oleh PT. Perkebunan Nusantara 2 (Persero) baik yang masih berstatus Hak Guna Usaha maupun dalam status dikeluarkan dari Hak Guna Usaha PT. Perkebunan Nusantara 2 (Persero), sampai ada kejelasan mengenai status hak tersebut. 
4. Pihak aparat penegak hukum dalam hal ini pihak kepolisian hendaknya berperan aktif dalam pengamanan lahan dimaksud agar tidak terjadi apa yang disebut dengan ladang pembantaian (the killing field). 


\section{DAFTAR PUSTAKA}

A Yahya Muhaimin. 1990. Bisnis dan Politik : Kebijaksanaan Ekonomi Indonesia 1950-1980, Jakarta LP3ES.

Adnin, Herdensi, Lahan Eks HGU PTPN II dan Masalah Konflik Agraria di Sumatera Utara, Sintesa, 20 Januari 2012.

Afnawi Nuh. 1998. Dari Petani Reba ke Petani Jaluran, dalam Pembangunan Berbuah Sengketa ; Kumpulan Kasus-kasus Sengketa Pertanahan Sepanjang Orde Baru. Medan : Yayasan Sintesa dan Serikat Petani Sumatera Utara (SPSU).

Anderson, John, Mission to the East Coast of Sumatra in 1823, Kuala Lumpur Singapore, Oxford University Press, London New York, 1971. -2010. Mencari Sistem Hukum Benda Nasional. Bandung PT. Alumni.

Bondan Kanumoyoso. 2001. Nasionalisasi Perusahaan Belanda di Indonesia, Op.Cit. Jakarta : Pustaka Sinar Harapan.

Edy Ikhsan. 2013. Antan Patah Lesungpun Hilang: Pergesran Hak Tanah Komunal dan Pluralisme Hukum dalam Perspektif Sosiolegal (Studi pada Etnis Melayu Deli di Sumatera Utara). Program Studi Doktor (S3) Ilmu Hukum, Fakultas Hukum Universitas Sumatera Utara.

Frederik, Willem Wertheim, Masyarakat Indonesia dalam Transisi : Studi Perubahan Sosial, Penerjemah Misbah Zulfa Elizabeth, Tiara Wacana, Yogyakarta, 1999.

Ian, Chalmers. 1996. Konglomerasi:Negara dan Modal dalam Industri Otomotif Indonesia, Jakarta : Gramedia Pustaka.

Jansen, Gerard, Granrechten in Deli, Uitgave van Sumatra-Instituut, 1925.

Kelsen, Hans, Teori Umum Hukum dan Negara Dasar-dasar Ilmu Hukum Normatif Sebagai Ilmu Hukum Deskriptif-Empirik, (Terjemahan Drs. H. Somardi), Media Indonesia, Jakarta, 2007.

Labberton, K, van Hinlopen, De Indische Landbow Concessie, Amsterdam, JH. De Bussy, 1903.

Mahadi. 1978. Sedikit Sejarah Perkembangan Hak-hak Suku Melayu Atas Tanah di Sumatera Timur" (Tahun 1800-1975). Bandung Alumni.

Mariam Darus Badrulzaman. 2001. Kompilasi Hukum Perikatan. Bandung : PT. Citra Aditya Bakti, Bandung.

OK Saidin. 1986. Hak-hak Rakyat Penunggu Atas Tanah Jaluran di Areal Perkebunan Tembakau PTP IX Sumatera Utara : Pergeseran Makna Juridis dan Fungsi Lahan (Sebuah Studi Nondoktrinal Riset).

------------, Keberadaan Hak Ulayat Kesatuan Masyarakat Hukum Adat di Kabupaten Deli Serdang, Hasil Penelitian Pemkab Deli Serdang, Lubuk Pakam, 2002.

------------, 42 Tahun UUPA: Hak Ulayat, Keberpihakan Setengah Hati, dalam harian Republika, tanggal 26 September 2002.

Orucu, Esin dan Elspeth Attwooll \& Sean Coyle. 1996. Studies in Legal Systems : Mixed and Mixing, Kluwer Law International, London/Boston.

Sri Soedewi Masjchoen Sofwan. 1981. Hukum Perdata : Hukum Benda. Yogyakarta Liberty. 1981.

Sutter, Jhon O., Indonesianisasi : Politics in a Changing Economy,1940-1955, Ithaca: Cornell University, Modern Indonesia Project, 1959.

Syamsuddin Ishak. 2011. Keindonesiaan : Persatuan yang Terhenti, Kesatuan yang Asimetris, Prisma, Volume 30, 2011, Jakarta : LP3ES.

T. Lukman Sinar. 1980. Sari Sejarah Serdang, Jilid I. 
The Bremen Tobacco Case .Departement of Information, Republic Indonesia, Jakarta, 1960.

\section{Peraturan Perundang-undangan :}

Kitab Undang-undang Hukum Perdata

Undang-undang No. 86 Tahun 1958 tentang Nasionalisasi Perusahaan-perusahaan Belanda.

Surat Keputusan Kepala BPN No. 42/HGU/BPN/2002, tanggal 22 Nopember 2002.

Surat Keputusan Kepala BPN No. 43/HGU/BPN/2002, tanggal 22 Nopember 2002.

Surat Keputusan Kepala BPN No. 44/HGU/BPN/2002, tanggal 22 Nopember 2002.

Surat Keputusan Kepala BPN No.10/HGU/BPN/2004 tanggal 6 Pebruari 2004. 